\title{
Optimalisasi Guru dalam Membuat Media Pembelajaran untuk Mestimulasi Kemampuan Kognitif Anak Usia Dini
}

\author{
Pahenra $^{1}$, Sitti Salma ${ }^{2}$, Nurlina ${ }^{3}$, Hasmira Said ${ }^{4}$, Asriana ${ }^{5}$ \\ Program Studi PG-PAUD, Universitas Muhammadiyah Kendari \\ Email Korespondesi: hendraanongko71@gmail.com
}

\begin{abstract}
Abstrak: Penelitian ini bertujuan untuk mengetahui kemampuan guru membuat media pembelajaran dalam menstimulasi kognitif anak usia dini di PAUD Monapa Kecamatan Palangga Kabupaten Konawe Selatan. Subjek penelitian ini adalah guru yang berjumlah dua orang dan kepala sekolah. Adpaun objeknya adalah anak didik berjumlah 15 orang di kelompok A. Teknik pengumpulan data menggunakan observasi, wawancara, dan dokumentasi yang diolah dan dianalisis melalui teknik deskriptif kualitatif. Upaya guru membuat media pembelajaran di PAUD Monapa Kecamatan Palangga Kabupaten Konawe Selatan langkah yang dilakukan dalam membuat media adalah menentukan media apa yang akan dibuat, menyediakan alat dan bahan, menyusun langkah-langkah pembuatan media dan prosedur penyampaiannya kepada anak didik. Media yang dibuat dari bahan sisa/bekas mudah didapatkan. Sementara itu, lingkungan sekolah jauh dari perkotaan sehingga guru sulit mendapatkan alat-alat yang dibutuhkan. Meskipun demikian, guru kreatif menggunakan bahan bekas atau bahan sisa untuk menciptakan media pembelajaran. Media yang dibuat guru bertujuan untuk menstimulasi kognitif anak.
\end{abstract}

Kata Kunci: Guru Terampil, Kognitif Anak, Media Pembelajaran.

\begin{abstract}
This study aims to determine the ability of teachers to make instructional media in stimulating early childhood cognitive in PAUD Monapa, Palangga District-South Konawe District. The subjects of this study were two teachers and the principal. Meawhile, the object was 15 students in group A. Data collection techniques used observation, interviews, and documentation which were processed and analyzed through qualitative descriptive techniques. The teacher's efforts to make learning media in PAUD Monapa, Palangga District, Konawe Selatan Regency, the steps taken in making the media are determining what media to make, providing tools and materials, compiling steps for making media and procedures for delivering it to students. Media was made from scraps / used materials is easy to get. Yet, the school environment is far from urban areas, so it is difficult for teachers to get the tools they need. Even so, creative teachers use used materials or waste materials to create learning media. The media created by the teacher aims to stimulate children's cognitive.
\end{abstract}

Keywords: Children's Cognitive, Learning Media, Skilled Teachers. 


\section{PENDAHULUAN}

Dunia pendidikan anak usia dini adalah sebuah era dimana tidak terlepas dari bermain sambil belajar dengan berbagai media permainan anak-anak. Salah satu lembaga pendidikan yang berperan penting dalam proses pembelajaran dan peningkatan mutu dunia pendidikan kanakkanak adalah pendidikan anak usia dini.

Sebagai sebuah taman, tentu saja pendidikan anak usia dini merupakan sebuah tempat belajar dan juga bermain kanak-kanak yang memiliki berbagai sarana dan prasarana untuk mendukung terlaksananya proses pembelajaran dengan baik dan berkualitas.

Media pembelajaran merupakan salah satu komponen penting dalam menentukan keberhasilan penyelenggaraan program pendidikan pada satuan Pendidikan Anak Usia Dini (PAUD). Sudono (2011) berpendapat bahwa media pembelajaran merupakan semua media bermain yang digunakan anak untuk memenuhi naluri bermainnya. Media tidak dapat dipisahkan dari kebutuhan anak usia dini. Selanjutnya Solehuddin (2012) berpendapat bahwa media pembelajaran pada pendidikan prasekolah hendaknya bersifat sederhana, konkrit, sesuai dunia kehidupan anak, terkait dengan situasi pengalaman langsung, atraktif, mengundang rasa ingin tahu, bermanfaat, dan terkait dengan aktivitas-aktivitas bermain anak. Banyak ragam bentuk media pembelajaran, baik yang berbentuk luar ruangan maupun dalam ruangan yang bias dimanfaatkan atau digunakan dalam proses pembelajaran.

Media pembelajaran dapat dimanfaatkan dalam proses pembelajaran pada satuan PAUD. Hal ini menyebabkan perlunya guru merancang media pembelajaran yang dapat menjadi alat untuk menstimulasi kemampuan kognitif anak. Pengembangan aspek kognitif anak bertujuan untuk meningkatkan kemampuan berpikir logis, menemukan hubungan sebab akibat, dan meningkatkan pengertian pada bilangan sehingga dapat menunjang perkembangan kognitif anak usia dini. Observasi yang peneliti telah lakukan pada sebuah lembaga PAUD yaitu PAUD Monapa Kabupaten Konawe Selatan, hal ini terlihat beberapa media pembelajaran yang dibuat oleh guru dari bahan-bahan bekas atau bahan sisa yang digunakan guru dalam menyampaikan informasi atau pesan pembelajaran kepada anak didiknya. Dengan adanya media-media pembelajaran yang dibuat oleh guru di PAUD Monapa sangat membantu guru dengan mudahnya memberikan pemahaman dan latihanlatihan kepada anak didiknya dalam mengembangkan seluruh aspek bidang pengembangan anak didiknya. Dari beberapa media yang dibuat oleh ibu guru PAUD Monapa terdapat media yang sangat menarik dari bahan bekas kardus yaitu bentuk rumah dan pohon. Media rumah angka dan pohon angka tersebut dapat menstimulasi aspek perkembangan anak terkhusus media tersebut dibuat oleh ibu guru untuk menstimulasi aspek perkembangan kognitif anak.

Pentingnya guru membuat atau merancang media pembelajaran adalah karena media merupakan alat yang dapat digunakan sebagai perantara dalam menstimulasi semua aspek perkembangan pada anak usia dini, baik dari segi aspek nilai agama dan moral anak, Aspek fisik motorik, sosial emosional, bahasa dan kognitif anak. Dalam menstimulasi aspek perkembangan anak usia dini utamanya stimulasi kognitif anak harus disesuaikan dengan usia dan tahapannya karena setiap anak walaupun memiliki usia yang sama tapi terkadang memiliki tahap perkembangan yang berbeda. Untuk menstimulasi seluruh aspek perkembangan anak dibutuhkan media pembelajaran dengan prinsip belajar dilakukan melalui bermain dengan menggunakan media pembelajaran sehingga kegiatan pembelajaran pada anak usia dini berjalan secara efektif. 
Berdasarkan Undang-Undang

Nomor 14 Tahun 2005 tentang Guru dan Dosen, pada pasal 10 ayat (1) menyatakan bahwa "Kemampuan guru sebagaimana dimaksud dalam Pasal 8 diantaranya meliputi kemampuan pedagogik. Kemampuan pedagogik adalah kemampuan pemahaman terhadap peserta didik, perancangan dan pelaksanaan pembelajaran, evaluasi hasil belajar, dan pengembangan peserta didik untuk mengaktualisasikan berbagai potensi yang dimilikinya. Sub kemampuan dalam kemampuan pedagogik adalah: 1) Memahami peserta didik secara mendalam yang meliputi memahami peserta didik dengan memanfaatkan prinsip-prinsip perkembangan kognitif, prinsip-prinsip kepribadian, dan mengidentifikasi bekal ajar awal peserta didik. 2) Merancang media pembelajaran, termasuk memahami landasan pendidikan untuk kepentingan pembelajaran yang meliputi memahami landasan pendidikan, menerapkan teori belajar dan pembelajaran, menentukan strategi pembelajaran berdasarkan karakteristik peserta didik, kompetensi yang ingin dicapai, dan materi ajar, serta menyusun rancangan pembelajaran berdasarkan strategi yang dipilih. 3) Melaksanakan pembelajaran yang meliputi menata latar (setting) pembelajaran dan melaksanakan pembelajaran yang kondusif. Dan 4) Merancang dan melaksanakan evaluasi pembelajaran yang meliputi merancang dan melaksanakan evaluasi (assessment) proses dan hasil belajar secara berkesinambungan dengan berbagai metode, menganalisis hasil evaluasi proses dan hasil belajar untuk menentukan tingkat ketuntasan belajar (mastery level), dan memanfaatkan hasil penilaian pembelajaran untuk perbaikan kualitas program pembelajaran secara umum. Serta 5) Mengembangkan peserta didik untuk mengaktualisasikan berbagai potensinya meliputi memfasilitasi peserta didik untuk pengembangan berbagai potensi akademik, dan memfasilitasi peserta didik untuk mengembangkan berbagai potensi non akademik.

Media adalah segala sesuatu yang dapat digunakan untuk menyalurkan pesan dari pengirim ke penerima sehingga dapat menstimulasi pikiran, perasaan, perhatian, dan minat serta perhatian anak didik sedemikian rupa sehingga proses belajar terjadi Sadiman (2002). Sementara itu, Latuheru (1988), memberikan pendapat lain tentang media pembelajarana adalah adalah bahan, alat, atau teknik yang digunakan dalam kegiatan belajar mengajar dengan maksud agar proses interaksi komunikasi edukasi antara guru dan anak didik dapat berlangsung secara tepat guna dan berdaya guna. Oleh karena itu guru harus memiliki pengetahuan yang cukup tentang media pengajaran, yang menjelaskan bahwa media adalah sebagai alat komunikasi guna lebih mengefektifkan proses belajar mengajar. Dan berfungsi media dalam rangka mencapai tujuan pendidikan,serta memiliki nilai atau manfaat media pendidikan dalam pengajaran,

Manfaat media dalam meningkatkan proses belajar mengajar adalah mengefektifkan interaksi atau komunikasi antara guru dengan peserta didi atau anak didik sehingga pembelajaran akan lebih baik dan efisien. Tetapi secara lebih khusus ada beberapa manfaat media yang lebih rinci yang dikemukan oleh Kemp dan Dayton (2012) adalah untuk mengidentifikasi beberapa manfaat media dalam pembelajaran yaitu: (1) Penyampaian materi pelajaran dapat diseragamkan,(2) Proses pembelajaran menjadi lebih jelas dan menarik, (3) Proses pembelajaran menjadi lebih interaktif, (4) Efisiensi dalam waktu dan tenaga, (5) Meningkatkan kualitas hasil belajar siswa , (6) Media memungkinkan proses belajar dapat dilakukan dimana saja dan kapan saja, (7) Media dapat menumbuhkan sikap positif siswa terhadap materi dan proses belajar,( 
8) Merubah peran guru ke arah yang lebih positif dan produktif. Jadi jelas bahwa media pembelajaran sangat penting dan berpengaruh dalam mestimulasi nilai nilia kemampuan kognitif anak.

Hamalik (2012) mengemukakan bahwa pemakaian media pengajaran dalam proses belajar mengajar dapat membangkitkan keinginan dan minat yang baru, membangkitkan motivasi dan rangsangan kegiatan belajar, dan bahkan membawa pengaruh-pengaruh psikologis terhadap anak didik. Media Pembelajaran banyak sekali jenis dan macamnya. Ada media yang paling sederhana sampai media yang paling canggih, ada yang murah da nada yang mahal serta ada yang local da nada nasional dan global, kemudian ada juga yang diproduksi manual serta pabrik. Media pembelajaran banyak tersedia dilingkungan sekitar kita dan bisa langsung kita manfaatkan, ada pula media yang secara khusus sengaja dirancang untuk keperluan pembelajaran terutama pembelajaran anak usia dini. Meskipun media banyak jenisnya, namun kenyataannya tidak banyak jenis media yang biasa digunakan oleh guru di sekolah khususnya pendidikan anak usi dini. Beberapa media yang paling akrab dan hampir semua sekolah memanfaatkan adalah media alam yang ada disekitar kita. Selain itu banyak juga sekolah yang telah memanfaatkan jenis media lain melaui visual atau audio visual dan obyek-obyek nyata. Sedangkan media lain seperti nimasi, online, film dan program pembelajaran lain yang sifatnya daring meskipun masih jarang digunakan namun sebenarnya sudah tidak asing lagi bagi sebagian besar guru.

Menurut Suyadi (2009:85) diuraikan cara guru merancang media pembelajaran yaitu harus mempunyai nilai edukatif tinggi dan bebas dari dampak negatif, yaitu Disesuaikan dengan perkembangan anak, Aman, Menyenangkan dan Mencerdaskan aspek tertentu, misalnya kognitif. Jean Piaget (2011: 210), teorinya disebut
"Cognitive Developmental". Dalam pendapatnya mengatakan bahwa proses berpikir sebagai aktivitas gradual dan fungsi intelektual dari konkret menuju abstrak. Dalam teorinya, Piaget memandang bahwa proses berpikir sebagai aktivitas gradual dari fungsi intelektual dari konkret menuju abstrak. Lebih lanjut mengatakan bahwa ada beberapa tahap tahap perkembangan pribadi seseorang serta perubahan umur yang mempengaruhi kemampuan belajar individu. Menurut Piaget lebih lanjut pertumbuhan kapasitas mental memberikan kemampuan-kemampuan mental yang sebelumnya tidak ada. Pertumbuhan intelektual adalah tidak kuantitatif, melainkan kualitatif. Dengan kata lain, daya berpikir atau kekuatan mental anak yang berbeda usia akan berbeda pula secara kualitatif. Sementara itu, pengklasifikasian perkembangan kognitif anak menjadi dibagi menjadi empat tahap: a) tahap pertama adalah tahap sensomotorik, yakni perkembangan ranah kognitif yang terjadi pada usia 0-2 tahun. Pada tahap ini disamakan dengan kegiatan motorik dan persepsi yang masih sederhana; b) Tahap Ke dua yaitu tahap preoperational, yakni perkembangan kemampuan kognitif yang terjadi pada usia 2-7 tahun. Tahap ini menjelaskan dimulainyamenggumakan symbol simbol yang telah dapat memperoleh pengetahuan berdasarkan pada kesan yang agak abstrak; c) Tahap ketiga yaitu tahap concreteoperational, yang terjadi pada usia 7-11 tahun. Tahap ini diidentikkan dengan perkembangan anak anak sudah mulai menggunakan aturan-aturan yang jelas dan logis. Anak sudah tidak lagi memusatkan diri pada hal hal yang sifatnya karakteristik perseptual pasif; d) dan tahap keempat yaitu tahap formal - operational, yakni perkembangan ranah kognitif yang terjadi pada usia 11-15 tahun. Ciri utama yang terjadi pada tahap ini adalah anak sudah mampu berpikir abstrak dan logis dengan menggunakan pola pikir yang nyata. 
Dalam pandangan Piaget, proses adaptasi seseorang dengan lingkungannya terjadi secara simultan melalui dua bentuk proses, asimilasi dan akomodasi. Asimilasi terjadi jika pengetahuan baru yang diterima seseorang cocok dengan struktur kognitif yang telah dimiliki seseorang tersebut. Sebaliknya, akomodasi terjadi jika struktur kognitif yang telah dimiliki seseorang harus direkonstruksi/di kode ulang disesuaikan dengan informasi yang baru diterima. Dalam teori perkembangan kognitif ini Piaget juga menekankan pentingnya penyeimbangan (equilibrasi) agar seseorang dapat terus mengembangkan dan menambah pengetahuan sekaligus menjaga stabilitas mentalnya. Equilibrasi ini dapat dimaknai sebagai sebuah keseimbangan antara asimilasi dan akomodasi sehingga seseorang dapat menyatukan pengalaman luar dengan struktur dalamya. Proses perkembangan intelek seseorang berjalan dari disequilibrium menuju equilibrium melalui asimilasi dan akomodasi. Anak didik PAUD merupakan anak yang berusia antara 3-6 tahun, yang memiliki potensi untuk tumbuh dan berkembang. Hal ini sesuai dengan hasil penelitian bahwa pada anak usia dini (0-8 tahun) merupakan masa emas (golden age) dimana terjadi pertumbuhan dan perkembangan kognitif, sel-sel otak dan berbagai aspek pada anak yang mencapai $80 \%$. Oleh karena itu pada masa ini, perlu usaha untuk menstimulasi agar kognitif anak dapat berkembang secara optimal. Banyak upaya dapat dilakukan untuk menstimulasi tumbuh kembang kognitif anak, salah satu diantaranya melalui media pembelajaran. Menurut Suyadi (2009: 91), alasan-alasan yang mendorong guru merancang media pembelajaran pada pelaksanaan proses pembelajaran pendidikan anak usia dini, antara lain: a) Dapat dijadikan sebagai substitusi media pembelajaran guna merangsang tumbuh kembang anak, khususnya kognitif; b) Dapat menjadi media guna menanamkan nilai-nilai budaya warisan nenek moyang yang telah punah, sehingga diharapkan akan terjadi transfer budaya kepada generasi penerus yang memiliki jati diri bangsanya; c) Media pembelajaran mudah dirancang atau dibuat oleh pendidik PAUD. Hal ini dikarenakan media pembelajaran memiliki bentuk yang simple (sederhana); d) Media pembelajaran dapat dimanfaatkan pada saat pembelajaran dengan mudah dan praktis.

\section{METODE PENELITIAN}

Jenis penelitian ini adalah penelitian kualitatif deskriptif sehingga keseluruhan data dan informasi yang terkumpul merupakan suatu hasil nyata yang berada di lapangan tanpa ada rekayasa atau pengaruh dari peneliti sendiri yang kemudian dideskripsikan dan dipresentasikan. Penelitian deskriptif merupakan penelitian yang dimaksudkan untuk mengumpulkan data dan informasi, mengenai status suatu gejala, peristiwa dan kejadian yang ada atau yang terjadi pada masa sekarang menurut apa adanya pada saat penelitian dilakukan, kemudian menguraikan dan memaparkan data dan informasi tersebut secara deskriptif pula.

Penelitian ini dilaksanakan pada bulan Juli sampai Agustus 2020. Bertempat di PAUD Monapa Kecamatan Palangga Kabupaten Konawe Selatan. Subjek penelitian adalah guru yang terdiri dari 2 orang guru dan kepala sekolah PAUD Monapa Kecamatan Palangga Kabupaten Konawe Selatan, dan objeknya adalah anak didik kelompok $A$ berjumlah 15 orang anak didik.

Teknik pengumpulan data dalam penelitian ini yaitu: 1) Observasi adalah metode pengumpulan data yang digunakan untuk menghimpun data penelitian melalui pengamatan dan pengindraan. 2) Teknik wawancara adalah usaha mengumpulkan informasi dengan mengajukan sejumlah pertanyaan secara lisan untuk dijawab secara lisan pula dengan ciri utama berupa kontak langsung dengan tatap muka (face to face relationship) antara si pencari informasi 
(interviewer atau information hunter) dengan sumber informasi (interview). 3) Teknik dokumentasi merupakan teknik pengumpulan data dengan sumber bukan manusia, non human resources, diantaranya dokumen, dan bahan statistik Pengolahan data yang telah dicatat dan dikumpulkan, dilakukan dengan menggunakan metode analisis data secara kualitatif-deskriptif dengan langkah sebagai berikut a) Reduksi data; yaitu data yang teramati dirangkum, dicatat dan disusun secara sistematis dan teratur mulai dari tahapan awal hingga akhir kegiatan; b) Penyajian data; yakni mengecek kelengkapan dan keabsahan data dengan teknik triangulasi data, tabulasinya, lalu memproses data yang telah ditabulasi itu, kemudian dianalisis atau diproses lebih lanjut dalam bentuk paparan deskriptifkualitatif dan dipresentasikan dengan menggunakan model kualitatif yang telah ditentukan; c) penarikan kesimpulan dan verifikasi dalam bentuk paparan logis sesuai keadaan apa adanya yang diperoleh peneliti dari hasil pencatatan observasi pengamatan langsung dilakukan, kemudian dari hasil catatan pengamatan itu dilakukan interpretasi sebagai jawaban terhadap permasalahan yang diajukan pada penelitian ini. Atas dasar hasil tersebut, peneliti dapat menarik kesimpulan akhir mengenai gambaran kemampuan guru merancang media pembelajaran dalam menstimulasi kognitif anak usia dini,

\section{HASIL PENELITIAN DAN PEMBAHASAN}

Penelitian yang dilaksanakan sejak tanggal 16 Juli sampai 4 Agustus tahun 2020 di PAUD Monapa yang beralamat di Kecamatan Palangga Kabupaten Konawe Selatan menunjukkan bahwa kemampuan guru membuat media pembelajaran dalam menstimulasi kognitif anak sangat terstruktur. Dengan mengetahui jelas isi pokok materi yang akan diajarkan, maka hal ini memudahkan guru untuk merancang media pembelajaran apa saja yang harus dibuat dan disampaikan kepada anak didik. Adapun kemampuan guru membuat media pembelajaran dalam menstimulasi kognitif anak dapat terlihat dengan jelas ketika guru membuat media pembelajaran 'Rumah Angka' dan 'Pohon Angka'.

Hasil observasi yang peneliti lakukan pada tanggal 16 Juli 2020, diperoleh data bahwa cara atau langkah-langkah guru membuat media pembelajaran dalam menstimulasi kognitif anak di PAUD Monapa Kecamatan Palangga Kabupaten Konawe Selatan, yakni sebagai berikut: (1) Rumah Angka: Rumah angka ini dibuat oleh guru dalam menstimulasi kemampuan kognitif anak, utamanya untuk mengenal angkaangka atau lambang bilangan. Adapun alat dan bahan yang digunakan guru dalam membuat atau merancang media pembelajaran yaitu rumah angka adalah gunting, lem, lilin, pisau kater, kardus, dan mistar. Setelah bahan-bahan atau alat yang akan digunakan dalam membuat media rumah angka guru memperlihatkan cara merancang dan membuat media rumah angka tersebut. Adapun cara membuat media rumah angka adalah pertama-tama guru menggunting kardus berbentuk persegi panjang sebagai lantai dari rumah angka, kemudian menggunting kardus berbentuk persegi panjang sebagai dinding dari rumah angka, setelah itu guru juga menggunting kardus berbentuk persegi panjang sebagai atap dari rumah angka. Setelah kardus digunting bentuk persegi panjang dan segitiga, guru lalu menyatukan bentuk-bentuk tersebut dengan menggunakan lem dan lilin sehingga terangkai menjadi bentuk rumah; (2) Pohon angka: Media pembelajaran pohon angka ini juga bertujuan untuk menstimulasi kemampuan kognitif anak. Dengan media pohon angka ini anak dapat mengenal angka-angka yang ada pada pohon angka tersebut. Adapun alat dan bahan yang digunakan dalam membuat atau merancang media pohon angka ini adalah gunting, lem, 
kertas karton dan kertas warna-warni. Cara pembuatan media pohon angka ini adalah guru menyediakan alat dan bahan terlebih dahulu, kemudian guru menggunting kertas karton tersebut berbentuk daun dan pohon, guru juga menggunting kertas karton berbentuk batang pohon dan ranting pohon. Setelah kardus digunting berbentuk pohon, ranting, daun dan batang pohon, guru juga menggunting bentuk tersebut di kertas berwarna-warni sesuai dengan pola batang pohon, ranting, dan daun. Setelah semuanya siap guru merangkai batang, ranting, dan daun pohon tersebut dengan menggunakan lem, sehingga sudah berbentuk pohon yang kemudian diberi nama "pohon angka". Kemudian guru menyiapkan angka-angka yang bisa ditempelkan di pohon angka tersebut.

Kedua kegiatan merancang media pembelajaran ini dapat penulis simpulkan bahwa, kegiatan ini terlaksana dengan baik karena telah direncanakan dengan matang sesuai prosedur rancangan media pembelajaran yang telah dirumuskan dalam KTSP PAUD Monapa Kecamatan Palangga Konawe Selatan. Sehingga tujuan pembelajaran yang ingin dicapai yaitu, terstimulasinya kognitif anak berkembang sesuai apa yang diharapkan.

Hasil pengolahan data penelitian menunjukkan bahwa kemampuan guru membuat media pembelajaran dalam menstimulasi kognitif anak yang dilaksanakan, memberikan nuansa tersendiri dalam pembelajaran pada anak usia dini untuk memperkuat hasil dari proses pembiasaan berpikir logis yang telah diajarkan di sekolah dan di rumah. Terlaksananya dengan baik kegiatan pembelajaran kemampuan guru membuat media pembelajaran dalam menstimulasi kognitif anak di PAUD Monapa Kecamatan Palangga Kabupaten Konawe Selatan ini tidak terlepas dari dukungan dan kesiapan sekolah untuk melaksanakan kegiatan tersebut. Terkait dengan cara atau langkahlangkah yang dilakukan guru dalam membuat media pembelajaran dalam menstimulasi kognitif anak adalah: a) Menyediakan alat dan bahan; b) Menggunting kardus berbentuk persegi panjang sebagai lantai dari rumah angka; c) Menggunting kardus berbentuk persegi panjang sebagai dinding dari rumah angka; d) Menggunting kardus berbentuk persegi panjang sebagai atap dari rumah angka; e) Menggunting kardus berbentuk segitiga sebagai langit- langit dari rumah angka; f) Selanjutnya membentuk 'Rumah Angka' menggunakan lem dan lilin; dan g) Setelah terbentuk 'Rumah Angka' lalu ditempelkan lah berbagai macam angka.

Penelitian ini juga tak luput dari keterbatasan keterbatasan atau faktor penghambat dan pendukung yaitu guru membuat media pembelajaran dalam menstimulasi kognitif anak adalah tersedianya bahan-bahan yang mudah didapatkan dan tidak harus dibeli karena menggunakan bahan-bahan bekas atau bahan sisa yang tidak dipakai lagi kemudian guru membuatnya sebagai bahan yang bermanfaat. Sedangkan faktor penghambat karena lokasi sekolah jauh dari kota jadi sulit untuk mendapatkan secara langsung bahanbahan seperti kertas warna-warni untuk memperindah media dan kemampuan guru masih terbatas dalam membuat media.

Media pembelajaran memiliki fungsi sebagai alat bantu untuk memperjelas informasi/pesan, yang dalam hal ini guru adalah pengirim pesan dan anak usia dini sebagai penerima pesan. Dengan adanya media pembelajaran mempermudah para pendidik dalam melaksanakan tugas mereka dalam membantu proses belajar anak didik mereka. Begitu pentingnya media pembelajaran harus dibuat dan disediakan oleh guru dalam mempermudah guru dalam menyampaikan pesan pembelajaran Hasil uraian tersebut di atas dapat peneliti simpulkan bahwa kemampuan guru membuat media pembelajaran yang diterapkan di PAUD Monapa Kecamatan Palangga Kabupaten Konawe Selatan, 
memperoleh dukungan dari berbagai pihak terutama pihak sekolah. Dan sangat memberi pengaruh positif terhadap perkembangan aspek kognitif anak.

\section{SIMPULAN}

Kemampuan guru membuat media pembelajaran terbukti dapat menstimulasi kecerdasan kognitif anak di PAUD Monapa Kecamatan Palangga Kabupaten Konawe Selatan. Kegiatan guru membuat media pembelajaran dapat terlaksana dengan baik karena menggunakan prosedur atau langkah-langkah yang telah disusun dalam membuat media pembelajaran. Adapun hal yang penting bagi guru perhatikan untuk membuat media adalah menentukan media apa yang harus dibuat, menyediakan alat dan bahannya, menentukan langkahlangkah pembuatan medianya dan cara penggunaannya. Guru dalam membuat media pembelajaran masih terdapat kendala karena lingkungan sekolah masih jauh dari perkotaan sehingga sulit untuk mendapatkan alat-alat yang digunakan, akan tetapi guru kreatif menggunakan bahan bekas atau bahan sisa untuk membuat media. Selain itu, bahan ini mudah sekali didapatkan di sekitar lingkungan sekolah. Pentingnya guru membuat media pembelajaran sangat membantu guru dalam menyampaikan pesan atau informasi kepada anak didik, utamanya untuk menstimulasi kognitif anak. Nilai positif yang dapat diperoleh anak dengan kemampuan guru membuat media pembelajaran, mereka dapat mengenal angka atau bilangan 1-5, dan memecahkan masalah sederhana.

\section{UCAPAN TERIMA KASIH}

Artikel ini tersusun atas kerjasama seluruh penulis. Kami menyadari jika artikel ini dibuat atas partisipasi banyak pihak, untuk itu penulis mengucapkan banyak terima kasih kepada semua orang yang telah ikut berkontribusi. Ucapan terima kasih juga peneliti berikan kepada editor
Journal of Education and Teaching (JET), Fakultas keguruan dan ilmu pendidikan, Universitas muhammadiyah kendari yang siap menyediakan media, dan telah memberikan saran, masukan, dan pelayanan untuk kesempurnaan artikel ini

\section{DAFTAR PUSTAKA}

Hamalik, Oemar. (2011). Manfaat Media Pembelajaran Anak Usia Dini, Jakarta: Rineka Cipta.

Latuheru. (2012). Media Pembelajaran Anak Usia Dini. Jakarta: Rineka Cipta.

Piaget, Jean. (2011). Teori Kognitif Anak Usia Dini. Jakarta: Penerbit Indeks.

Sadiman. (2002). Media Pembelajaran Anak Usia Dini. Jakarta: Rineka Cipta.

Solehuddin. (2012). Media Pembelajaran Anak Usia Dini. Jakarta: Rineka Cipta. Sugiyono. (2014). Metode Pembelajaran Kuantitatif, Kualitatif dan Research \& Development. Bandung: Alfabeta.

Suyadi. (2009). Cara Guru Merancang Media Pembelajaran. Jakarta: Depdiknas.

Undang Undang Nomor 14 tahun 2005, Konsep Kemampuan Guru. Jakarta: Depdiknas 